\title{
A survey of chewing lice of some raptors in southern Iraq, with remarks on prevalence and occurrence
}

\author{
A.N. Hatem ${ }^{1}$, M.K. Abou Turab ${ }^{1}$, H.K. Abdul-Zahra ${ }^{2}$ and M.J. Muhammad ${ }^{1}$ \\ ${ }^{1}$ Biology Department, College of Education for Pure Sciences, ${ }^{2}$ General Directorate for Education of Basrah, Basrah, Iraq
}

\section{Article information \\ Article history: \\ Received February 21, 2020 \\ Accepted April 25, 2020 \\ Available online November 5, 2020}

\section{Keywords:}

Chewing lice

Raptors

Iraq

\author{
Correspondence: \\ A.N. Hatem \\ alaa.hatem@uobasrah.edu.iq
}

\begin{abstract}
This study was conducted to isolate and identify the chewing lice from some raptors in Basrah, Thi-Qar, and Missan provinces located in south of Iraq. Samples of birds were collected from January to December 2018. The survey was accomplished with a total of 87 raptors belonging to five species, sparrow hawk Accipiter nisus, marsh harrier Circus aeruginosus, lesser kestrel Falco naumani, kestrel Falco tinnuculus, and black kite Milvus migrans. Totally 58 of 87 birds were infested with chewing lice, the overall prevalence was 66.67\%. Five chewing lice species were identified: Craspedorrhynchus platystomus, Degeeriella fulva, Degeeriella fusca, Degeeriella rufa, and Laemobothrion maximum. All these species were identified in Iraq for the first time. D. rufa was recorded the highest prevalence in all raptors with $28.74 \%$, whereas $C$. platystomus was the lowest $10.34 \%$. As for the prevalence of bird's species, the highest percentage was recorded in kestrels and black kite with $71.43 \%$, while sparrow hawk was the lowest $53.85 \%$. Some notes about ecology and occurrence of the chewing lice were reported.
\end{abstract}

DOI: $10.33899 /$ ijvs.2020.126717.1365, , 2021 , College of Veterinary Medicine, University of Mosul.

This is an open access article under the CC BY 4.0 license (http://creativecommons.org/licenses/by/4.0/).

\section{Introduction}

The lice (order: Phthiraptera) are adapted successful insect ectoparasites of birds and mammals. This order is divided into four suborders: Anoplura, Amblycera, Ishnocera and Rhynchophthirina (1). The Anoplura is described as sucking lice, Amblycera and Ishnocera are described as chewing lice, and they are usually described into one suborder called Mallophaga (2). Chewing lice are permanent obligate ectoparasites (3). These parasites constitute about 3500 species of chewing lice worldwide (4). Many species of lice exhibit a high degree of host specificity. The life cycle of lice is complicated on the body of the host (5). Chewing lice have mouthparts designed for biting; they feed on feathers and dermal debris (6). These parasites can be harmful to domestic and wild birds; they can cause some pathological effects (2). These conditions cause some changes in body mass, flight performances; thermoregulatory capacity, and survival $(1,7)$. Sometimes could lead to serious problems, even to death in birds, and decreased egg production (5). Migratory birds were played an essential role in the parasite transmission to domesticated birds and fishes (7). The birds in Iraq were very diverse and may number 410 species (8). Birds were infected with a wide variety of ectoparasites such as lice, mites, ticks, hippoboscid flies, fleas and fly larvae (1).The previous studies of raptors in Iraq focused on identification and distribution of these birds. The information about parasitic infections of raptors in Iraq is very limited. Therefore, the aims of current study to identify the species diversity of the chewing lice fauna of raptors collected from three provinces located South of Iraq, Basrah, Thi-Qar, and Maissan provinces.

\section{Materials and methods}

\section{Study area}

This study was conducted in three provinces located at South of Iraq: Basrah, Thi-Qar and Maissan. This area is confined approximately within $45^{\circ}-49^{\circ}$ longitude and $30^{\circ}$ $33^{\circ}$ latitude. In this region are the Tigris, Euphrates, Shatt al- 
Arab rivers, and some of permanent and seasonal marshes. Although it's surrounded by Arabian Desert, the western mountains of Iran coalesces, and Arabian Gulf. The lands of this region are agricultural plains, semi-desert lands and deserts.

\section{Raptors collection}

This study carried out between January to December 2018. Raptors were borrowed from amateur people in the collection and breeding of birds, from 13 locations in South of Iraq. A total of 87 specimens belonging for five species obtained during the survey. Two of the birds' species are endemic: marsh harrier Circus aeruginosus, and kestrel Falco tinnuculus. Other three species are migratory: sparrow hawk Accipiter nisus, lesser kestrel Falco naumani and black kite Milvus migrans.

\section{Collection and Identification of chewing lice samples}

The birds were accurately examined for the chewing lice infestations. The beak and legs of the bird were restrained by adhesive tape for 30-60 minutes, so that the body could be easily held. The examination involved a search on body regions of bird: head, neck, abdomen, breast, wings, and tail. The lice preserved in $70 \%$ ethanol, then cleared in $10 \% \mathrm{KOH}$ and washed with distilled water, passed in ethanol series $70 \%, 80 \%, 90 \%$ and $100 \%(9,10)$. Some of lice specimens mounted on slides in Canada balsam and examined by compound microscope to use them in the diagnosis. The identification of chewing lice species was carried out according to some studies (9-13). The most diagnostic characters were used in the identification of lice as follows, body size, head shape, sutures, antenna, setae, terga, sternal plates and ganglia.

\section{Study of parasitism measures of chewing lice}

The total prevalence of chewing lice infestations of all raptors was recorded, and of each species of chewing lice. Some important measures of parasitism were recorded according to the following equations $(5,6,14)$. Prevalence $=$ number of individuals of a raptor species infested with a particular chewing lice species $\div$ number of raptors examined. Mean of intensity $=$ total number of individuals of a particular lice species in a sample of a raptor species $\div$ number of infested individuals of the raptor species in the sample. Relative density $=$ total number of individuals of a particular lice species in a sample of raptor $\div$ total number of individuals of the raptor species (infested + uninfected) in the sample. The location or attachment site of biting lice species in the bird's body and concurrent infestation was observed.

\section{Study of the seasonal occurrence}

Temperature means and relative humidity rates for the months in the study period were adopted by Iraqi meteorological organization and seismology in Basrah
Airport. The occurrence of infestations during the months of the year was recorded, and observed the relationship between the occurrence of infestations and the variations in temperature and relative humidity.

\section{Statistical analysis}

The results were analyzed with $t$ test and chi-square analysis by using SPSS program (computerized Statistical Program for Social Sciences). P value $<0.05$ was considered to be lest limit of significance. The Yates correction factor was incorporated into the chi-square calculation, whenever the test possessed less than two degrees of freedom.

\section{Results}

\section{Prevalence and diversity of chewing lice in raptors}

The results of the study showed that chewing lice were infested 58 of 87 specimens of raptors with total prevalence $66.67 \%$. Five species of chewing lice were isolated. The species recorded in this survey were as follows: Craspedorrhynchus platystomus Burmeister,1838, Degeeriella fulva Giebel, 1874, Degeeriella fusca Denny,1842, Degeeriella rufa Burmeister,1838 (family: Philopteridae), and Laemobothrion maximum Scoli, 1763 (family: Laemobothrionidae) Figures 1-5. All the species were recorded in Iraq for the first time.

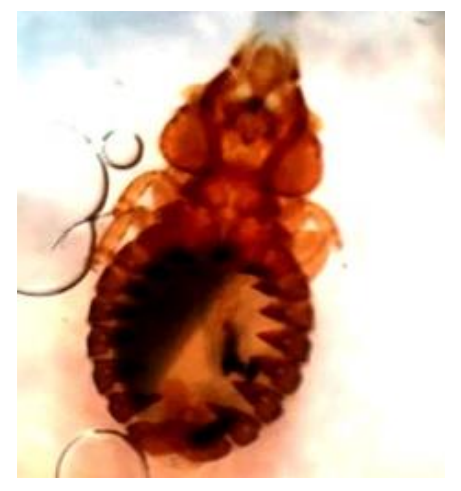

Figure 1: Craspedorrhynchus platystomus male (10X).

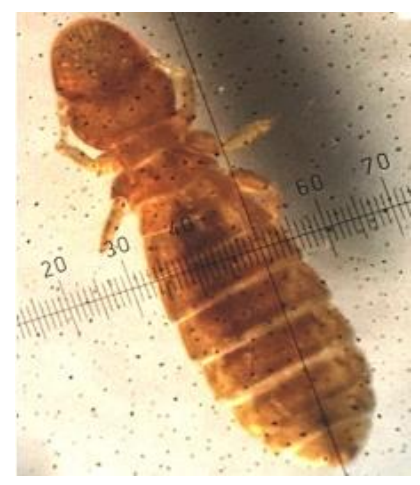

Figure 2: Degeeriella fulva female (10X). 


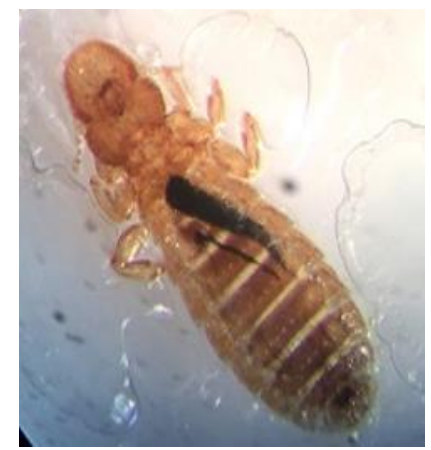

Figure 3: Degeeriella rufa female (10X).

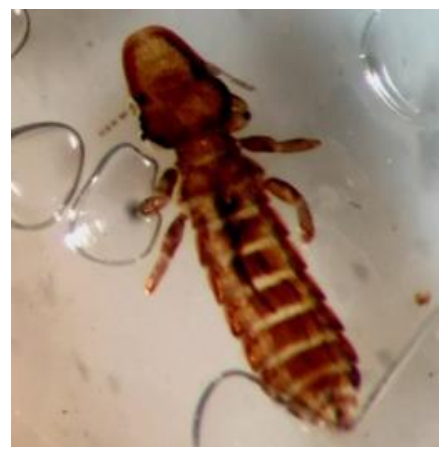

Figure 4: Degeeriella fusca male (10X).

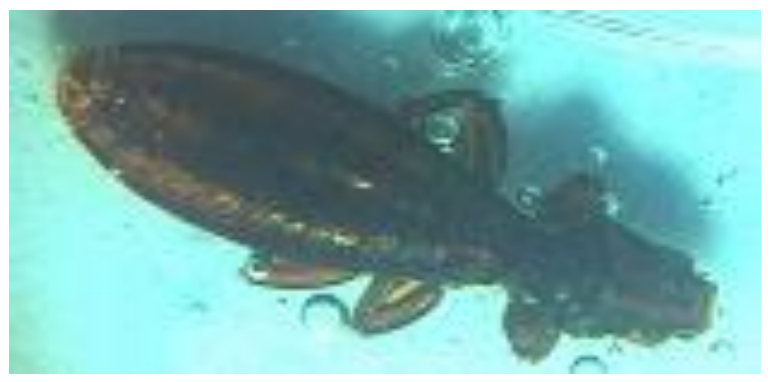

Figure 5: Laemobothrion maximum female (4X).

\section{Measures of parasitism of lice species}

Table 1 showed the total numbers of chewing lice specimens collected in the study. The species D. rufa was recorded the highest prevalence of lice in studied raptors with $28.74 \%$, while $C$. platystomus was the lowest abundance with $10.34 \%$. Statistical analyzes showed a significant difference between the prevalence of $D$. rufa and the other species, which did not differ significantly between them. The mean of intensity of chewing lice infestation was 5.24 in D. rufa, whereas the lowest was 3.36 in D. fulva. Based on statistical analysis of lice collection data, some significant differences were found between the mean of intensity of isolated lice species. The highest relative density of chewing lice was in $D$. rufa with 1.51 , whereas the lowest in $D$. fulva with 0.43 . The statistical analyzes showed a significant difference between the relative density of $D$. rufa and the other species, which did not differ significantly between them.

\section{The infestations depending on the raptors species}

Table 2 explained the numbers of infestation with chewing lice according the raptors species. The prevalence of infestations in each bird, it has been shown, the highest prevalence was recorded in $F$. naumani and $M$. migrans with $71.43 \%$. Significant differences were recorded between the previous species with $C$. aeruginosus, and A. nisus which recorded the lowest prevalence 53.85\%. Figure 6 show the diversity of chewing lice species infesting some raptors in southern Iraq. Falco tinnuculus and Falco naumani, $C$. aeruginosus and $M$. migrans have been infested with three species of chewing lice, whereas the two other raptors infested with two species. This figure also showed the numbers of infestation cases of lice species in the studied raptors. Figure 7 indicated that the patterns (concurrent) of infestations of raptors with chewing lice species were ranged between single to triple. The double infestations were the highest with $58.62 \%$ followed by single then triple. Based on statistical analysis of lice collection data, a significant differences were found between the types of concurrent infestations of raptors with isolated lice species.

\section{Ecology of chewing lice}

Table 3 showed some variations in the chewing lice infestations on the bodies of raptors. The infestations were recorded in many sites of the birds' body. D. fulva and $D$. rufa was collected from four sites on the raptors bodies, while $L$. maximum was founded in the wings only. The head is the most site of the bird's body in which chewing lice are present, where they found four species. While the lowest is the lower abdomen, where there is only one species.

Table 1: Total presence of chewing lice species isolated from examined raptors in southern Iraq

\begin{tabular}{lcccccc}
\hline lice species & $\begin{array}{c}\text { No. examined } \\
\text { raptors }\end{array}$ & $\begin{array}{c}\text { No. infested } \\
\text { raptors }\end{array}$ & Prevalence \% & $\begin{array}{c}\text { No. collected } \\
\text { lice }\end{array}$ & $\begin{array}{c}\text { Mean of } \\
\text { intensity }\end{array}$ & $\begin{array}{c}\text { Relative } \\
\text { density }\end{array}$ \\
\hline C. platystomus & 87 & 9 & 10.34 & 45 & 5.00 & 0.52 \\
D. fulva & 87 & 11 & 12.64 & 37 & 3.36 & 0.43 \\
D. fusca & 87 & 10 & 11.49 & 45 & 4.50 & 0.52 \\
D. rufa & 87 & 25 & 28.74 & 131 & 5.24 & 1.51 \\
L. maximum & 87 & 13 & 14.94 & 55 & 4.23 & 0.63 \\
\hline
\end{tabular}


Table 2: Prevalence of raptors infestation with chewing lice in southern Iraq

\begin{tabular}{lccc}
\hline Raptor species & No. examined & No. infested & Prevalence \% \\
\hline A. nisus & 13 & 7 & 53.85 \\
C. aeruginosus & 16 & 10 & 62.50 \\
F. naumani & 21 & 15 & 71.43 \\
F. tinnuculus & 23 & 16 & 69.57 \\
M. migrans & 14 & 10 & 71.43 \\
\hline Total & 87 & 58 & 66.67 \\
\hline
\end{tabular}

Table 3: Distribution of chewing lice species in the bodies of the raptors studied depending on the site of attachment (+) Indicate the presence of lice infestation at this site of the bird's body, (-) no infestation

\begin{tabular}{lccccccc}
\hline Lice species & Head & Neck & Wing & Breast & Abdomen & Tail & Anus \\
\hline C. platystomus & + & + & - & - & - & - & - \\
Degeeriella fulva & + & - & + & - & - & + & + \\
Degeeriella rufa & + & + & + & + & - & - & - \\
Degeeriella fusca & + & + & - & - & + & - & - \\
L. maximum & - & - & + & - & - & - & - \\
\hline
\end{tabular}

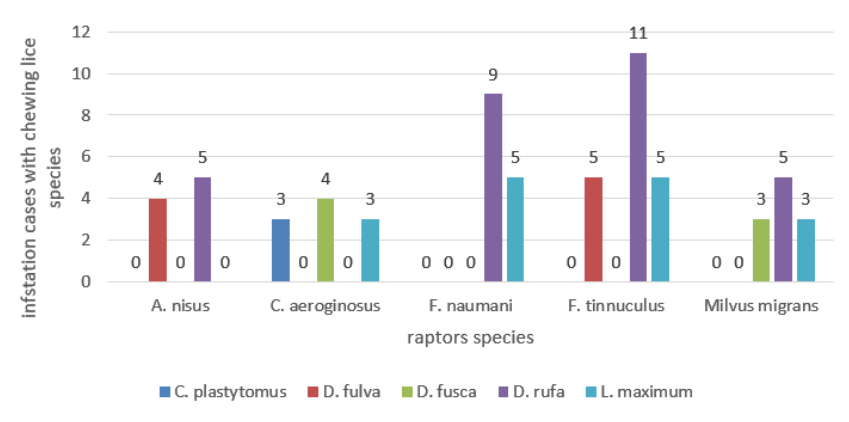

Figure 6: The diversity of chewing lice species infesting some raptors, and the number of infestation cases.

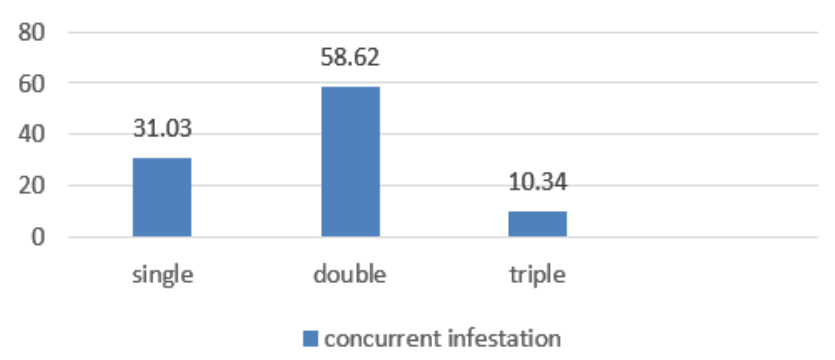

Figure 7: Concurrent infestation of chewing lice species in the examined raptors.

\section{The seasonal occurrence of chewing lice}

Figure 8 revealed that isolation of chewing lice from collected raptors from southern Iraq has been concentrated in the autumn, winter and spring months (when temperature varied between $12^{\circ}-30^{\circ}$ ). In January and February, the highest occurrence of chewing lice collection was recorded with $20.69 \%$, followed by December $18.97 \%$. The results of the statistical analysis showed that the rates of lice collection in these three months significantly exceeded that collected in the rest of the year. No samples of chewing lice were collected in August.

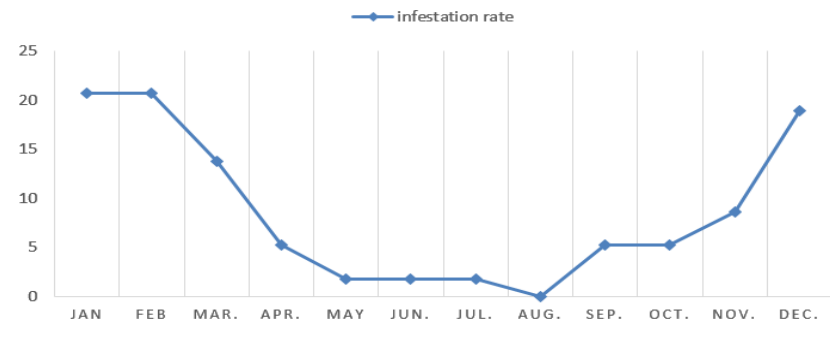

Figure 8: Seasonal occurrence of chewing lice on some raptors studied in southern Iraq for the period from January to December 2018.

\section{Discussion}

The results of the present study show a variety of chewing lice species infesting raptors in southern Iraq. The diversity of chewing lice species on raptors may be due to some reasons, including host defense, body size and shape and amount of feathers (13). Some reports have demonstrated significant correlations between lice species diversity and host body size, local population density, and geographic range size (6). There are a correlation between the abundance and species richness, and that between the mean abundance and host body mass (14). In this regard, Dik (9) showed that many chewing lice usually parasitize on specific host, but some can found on different hosts. Some studies about the chewing lice in Iraq, and focused on chicken and pigeons. In southern Iraq there are few studies on chewing lice. In Basrah Province there were four studies about the chewing lice were conducted, all these researchers 
studied on chickens and pigeons only. In Thi-Qar province, Mohammad (15) were studied the abundance of chewing lice on some aquatic birds. Of global studies on external parasites of raptors, Morishita et al. (16) isolated ten species of lice in California State. Gonzales et al. (17) studied chewing lice in diurnal raptors in Chile. Dik et al. (9) identified ten species of lice from some raptor birds in Turkey. De Olivera et al. (18) isolated three species of lice from hawks in Mexico. Liebana et al. (19) recorded two species in Argentina from kestrels. Grisign et al. (20) recorded nine species of lice from wild birds in North of Turkey. Tomas (21) founded seven species in raptors in Portugal.

The results also explained that lice species varied in attachment sites of the birds' body. The high prevalence of chewing lice on birds is complex with the fact that they are not given any form of body treatment (1). The ability of lice to stay attached to the host may also control analyses of Harrison's Rule in swift lice reveal a big correlation (13). Some species attached to bird feathers by means of a tarsal claws, and a close match between lice and host size may be preserve by selection for coherence, staying attached during bird flight (12). The correlation between louse and bird size in the genus Columbicola, is likely selected by bird preening, since wing of lice escape preening by inserting between the barbs of feathers (6). The population of lice affected with some factors though to influence population dynamics and age structure (8). Some differences between chewing lice in attachment sites of raptors bodies (6). Lice populations are normally controlled by host grooming and other factors, increasing in louse populations can degrade host condition, reproductive success and survival (22).

The difference in the seasonal occurrence of chewing lice during the study period is due to the monthly presence of raptors. The migration of birds due to climatic conditions may affect the seasonal occurrence, distribution and diversity of chewing lice (23). The ecological conditions, temperature and humidity are very important to determine seasonal variation of chewing lice infestations (6). High temperature with low humidity are effected in the lice abundance (24). The geographical location and seasonality may be responsible for distribution of infestation rates of chewing lice $(25,26)$. There may be several other factors affecting the presence of chewing lice on raptors, including the size of the body of the bird and its shape, behavior and habitat $(23,27)$.

\section{Conclusion}

This study concludes that high prevalence of chewing lice on raptors in South of Iraq. These birds may also be acting as reservoir hosts for ectoparasites transmission to domestic birds because they are migratory, and some are epidemic. This information will therefore be interesting to evaluate the effects that these parasites on birds' health, and also to establish the type of diseases they transmit between different birds. The results of the present study may contribute to the increased understanding of epidemiology of ectoparasites of the birds in Iraq.

\section{Acknowledgments}

The authors would like to thank all who helped them in this research. Especially Dr. Bilal Dik and Dr. Dhia Kareem gave us some references about lice identification.

\section{Conflict of Interest}

The authors assert that there are no conflicts of interest with other researchers or institutions.

\section{References}

1. Wall RL, Shearer D. Veterinary ectoparasites: Biology, pathology and control. New York: John Wiley and Sons. 2008; 271 p. Doi: $10.1002 / 9780470690505$

2. Durden LA. Lice (Phthiraptera), in medical and veterinary entomology. London: Elsevier. 2019; 79-106 p. Doi: 10.12933/therya-19-784

3. Johnson KP, Clayton DH. The biology, ecology, and evolution of chewing lice. Illinois Nat Hist. 2011; 24:449-476. Doi: 10.3906/zoo1411-45

4. Hopkins G, Clay T. A check list of the genera and species of Mallophaga. London: Elsiver; 1952; 425 p. Doi: 10.11646/zootaxa.1899.1.1

5. Smith VS. The chewing lice: World checklist and biological overview. London: Special Publication; 2003; 501 p. Doi: org/10.1080/10635150490468521

6. Clayton D, Walther B. Influence of host ecology and morphology on the diversity of Neotropical bird lice. Oikos. 2001;94: 455-467. Doi: 10.1034/j.1600-0706.2001.940308.x

7. Clayton DH. Host specifity of Strigiphilus owl lice (Ischnocera: Philopteridae), with the description of new species and host associations. J Med Entomol. 1990;27:257-265. Doi.org/10.1093/jmedent/27.3.257

8. Hasan MH. Detection of ectoparasites in different birds, Iraqi J vet Sci. 2019;33(2):37-41. Doi: 10.33899/ijvs.2019.162896

9. Dik B, Yamaç EE, Uslu U. Chewing lice (Phthiraptera) found on wild birds in Turkey. Kafkas Univ Vet Fak Derg. 2011;17:787-794. Doi: 10.1016/j.ijppaw.2013.07.001

10. Clayton D. Host Specificity of Strigiphilus Owl Lice (Ischnocera: Philopteridae), with the Description of New Species and Host Associations. J Med Entomol. 1990;27(3):257-265. Doi.org/10.1093/jmedent/27.3.257

11.Tandan BK. Mallophaga parasites from Indian birds. Trans Ento Soc London. 1958;110:393-410. Doi: 10.1002/mmnd.19820290114

12. Price RD, Hellenthal RA, Palma RL. World checklist of chewing lice with host associations and keys to families and genera. 2013;1:448. Doi: 10.11646/zootaxa.2138.1.1

13. Clayton D, Gregory R, Price R. Comparative ecology of neotropical bird lice (Insecta: Phthiraptera). J Anim Ecol. 1992;781-795. Doi: 10.1002/mmnd.19820290114

14. Lesko MJ, Smallwood JA. Ectoparasites of American Kestrels in Northwestern New Jersey and Their Relationship to Nestling Growth and Survival. J Raptor Res. 2012;46(3):304-313. Doi.org/10.3356/JRR$11-56.1$

15. Mohammad ZA. Some chewing lice (Phthiraptera) species as ectoparasites infested aquatic birds with a new record of three species from Al-Sanaf marsh/ southern Iraq. Iraqi J Vet Sci. 2020; 34(1):173180. Doi: 10.33899/ijvs.2019.125721.1139

16. Morishita TY, Mertins JW, Baker DG, Monahan CM, Brooks DL. Occurrence and species of lice on free-living and captive raptors in 
California. J Avi Med Surg. 2001;15:288-293. Doi: 10.1647/10826742(2001)015[0288:OASOLO]2.0.CO;2

17. González-Acuña D, Ardiles K, Barrientos C, González P, Moreno L, Cicchino A. Lice of Chilean diurnal raptors. J Raptor Res. 2008;42:281287. Doi: $10.3356 / 0892-1016 . C O ; 2$

18. De Oliveira J, Santos T, Vaughan C, Santiago H. External parasites of raptors (Falconiformes and Strigiformes): Identification in an ex situ population from Mexico. Revista Biol Trop. 2011; 59, 1257-1264. Doi: 10.15517/rbt.v0i0.3396

19. Liébana MS, Santillán MÁ, Cicchino AC, Sarasola JH, Martínez P, Cabezas S, Bó MS. Ectoparasites in free-ranging american kestrels in Argentina: implications for the transmission of viral diseases. J Raptor Res. 2011;45:335-342. Doi: 10.3356/JRR-11-26.1

20. Girisgin AO, Dik B, Girisgin O. Chewing lice (Phthiraptera) species of wild birds in northwestern Turkey with a new host record. Inter $\mathbf{J}$ Parasitol. 2013;2:217-221. Doi: 10.1016/j.ijppaw.2013.07.001

21. Tomás A1, Palma RL, Rebelo MT, da Fonseca IP. Chewing lice (Phthiraptera) from wild birds in southern Portugal. Parasitol Int. 2016;65(3):295-301. Doi: 10.1016/j.parint.2016.02.007

22. Fabiyi J. Association between duration of humid season and geographical distribution patterns of different species of chewing lice (Mallophaga: Insecta) infesting domestic chickens in Nigeria. J Parasitol. 1996;1034-1036. Doi: 10.2307/3284220

23. Palma RL, Jensen JK. Lice (Insecta: Phthiraptera) and their host associations in the Faroe Islands, Steenstrupia, Copenhagen. Denmark. 2005;29:49-73. Doi:10.1.1.733.3152

24. Morand S, Hafner MS, Page RD. Comparative body size relationships in pocket gophers and their chewing lice. Biol $\mathrm{J}$ Linnean Soc. 2000;70:239-249. Doi: 10.1111/j.1095-8312.2000.tb00209.x

25. Inci A, Dik B, Kibar M, Duzlu O. Chewing lice (Phthiraptera) species on wild birds in Cappadocia region, Turkey. Turkiye Parazitolojii Dergisi. 2010; 34(4):174-178. Doi: 10.5152/tpd.2010.07

26. Prastowo J, Priyowidodo D, Nurcahyo W, Chusnaifah DL, Wusahaningtyas LS, Firdausy LW, Sahara A. Lice infestation and diversity in turkeys in the Special Region of Yogyakarta and Central Java, Indonesia. Vet World, 2019;13(4):782-788. Doi: 10.14202/vetworld.2020.782-788

27. Jeyathilakan N, Latha BR, Bino Sundar ST, Abdul Basith S. Occurrence of Laemobothrion maximum in Greater Coucal. J Parasit Dis, 2012; 36(1):120-121. Doi: 10.1007/s12639-011-0094-8

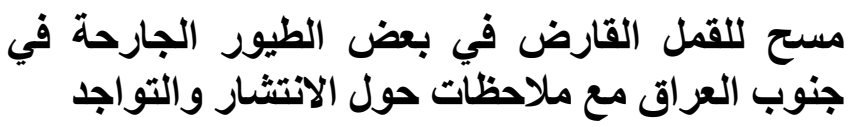

محمد جاسم محمد' حاظم'، مفيد قاسم أبو تراب'، هثام خير الله عبد الزهرةّ و

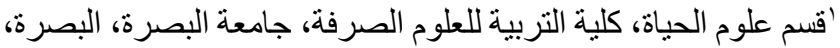

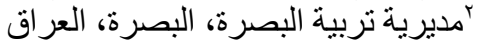

الخلاصة

أجريت هذه الدر اسة لعزل ونتخيص القمل القارض من بعض الطيور

الجارحة في محافظات البصرة وذي قار و وميسان ، جمعت عينات الطيور

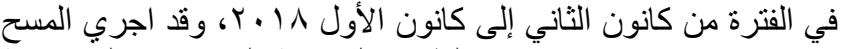

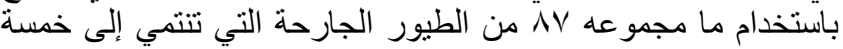

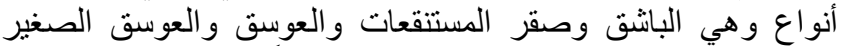

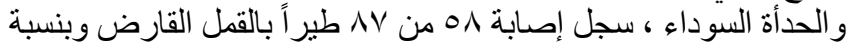

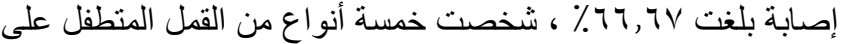
هذه الطيور وهي: Craspedorrhynchus platystomus و هن Degeeriella و Degeeriella fusca و Degeeriella fulva Laemobothrion maximus و rufa

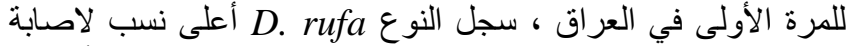

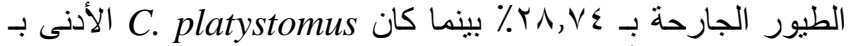

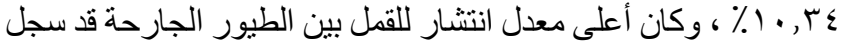

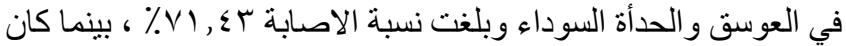

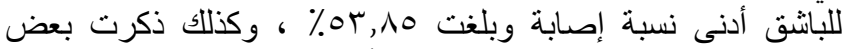

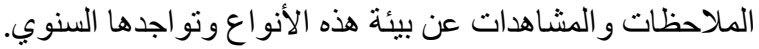

